\title{
Problematika Guru Pendidikan Agama Islam dan Budi Pekerti Pada Masa Pandemi Covid-19
}

\author{
Yesi Gusmita1, Rahmi Wiza² \\ yessigusmitha04@gmail.com ${ }^{1}$, rahmiwiza@fis.unp.ac.id ${ }^{2}$ \\ Universitas Negeri Padang1,2
}

\begin{tabular}{|c|c|}
\hline ARTICLE INFO & ABSTRAK \\
\hline Article history: & \multirow{13}{*}{$\begin{array}{l}\text { Penelitian ini dilatarbelakangi } \\
\text { problematika pada pembelajaran Pendidikan Agama } \\
\text { Islam dan Budi Pekerti (PABP) yang terjadi pada kelas } \\
\text { 8. Penelitian ini bertujuan untuk mendeskripsikan } \\
\text { permaslahan pembelajaran PABP yang dilaksanakan } \\
\text { oleh guru dan siswa kelas } 8 \text { serta solusi bagi } \\
\text { permasalahan yang dihadapi. Penelitian ini } \\
\text { menggunakan pendekatan kualitatif dengan } \\
\text { menggunakan metode studi kasus (case studies). } \\
\text { Pengambilan sampel dilakukan dengan teknik } \\
\text { purposive sampling. Pengumpulan data dilakukan } \\
\text { dengan teknik wawancara, observasi dan } \\
\text { dokumentasi. Data dianalisis dengan menggunakan } \\
\text { teknik data reduction, display data dan } \\
\text { verification/conclusion. Dan untuk menguji keabsahan } \\
\text { data menggunakan teknik triangulasi dan member } \\
\text { check. Berdasarkan hasil penelitian dapat disimpulkan } \\
\text { bahwa guru PABP mengalami beberapa kesulitan } \\
\text { dalam mengajar PABP di kelas } 8 \text { SMP Negeri 12 Solok } \\
\text { Selatan pada masa Pandemi Covid-19 tahun ajaran } \\
\text { 2020/2021. }\end{array}$} \\
\hline Received 5 Agustus 2021 & \\
\hline & \\
\hline & \\
\hline Acce & \\
\hline & \\
\hline Keywords: & \\
\hline $\begin{array}{l}\text { Problematika, } \\
\text { Pembelajaran, PABP }\end{array}$ & \\
\hline & \\
\hline Clonflict of Interest: & \\
\hline None & \\
\hline Funding: & \\
\hline None & \\
\hline
\end{tabular}

Corresponding Author: Yesi Gusmita, Department Islamic Education, Faculty of Social Science, Universitas Negeri Padang, Indonesia, Email: yessigusmitha04@gmail.com Phone: +62812-1370-2637

(c) (i) Copyright(C2021, Author(s)

\section{Pendahuluan}

Penelitian ini memiliki perbedaan dengan penelitian yang dilakukan sebelumnya oleh Suci febriyantika Rahman (2020) yang berjudul: Problematika Pembelajaran Pendidikan Agma Islam (PAI) Pada Masa Pandemi Covid-19 di SMP Islam Nurussalam Al-Khoir Mojolaban Sukoharjo Tahun Pelajaran 2019/2020. Perbedaannya adalah terdapat pada sistem pembelajaran yang diteliti, pada penelitian sebelumnya meneliti pembelajaran secara daring sedangkan sistem pembelajaran yang diteliti penulis berupa pembelajaran secara daring kombinasi luring dan juga pembelajaran tatap muka. 
Penelitian ini dilatarbelakangi dengan menjangkitnya virus corona di Indonesia yang semakin membatasi ruang gerak masyarakat dalam beraktifitas. Akibatnya pemerintah membuat banyak kebijakan termasuk kebijakan untuk bekerja dari rumah atau Work From Home (WFH). Kebijakan ini memerintahkan masyarakat untuk melaksanakan pekerjaan dari rumah. Virus corona memberikan dampak pada semua sektor kehidupan termasuk pada bidang pendidikan. Pemerintah melalui Kementerian Pendidikan dan Kebudayaan (Kemendikbud) telah menerapkan kebijakan learning from home atau Belajar dari Rumah (BDR) terutama pada satuan pendidikan yang berada di wilayah zona kuning, oranye dan merah. Dalam UndangUndang No. 20 Tahun 2003 Pasal 1 Ayat 15, dijelaskan bahwa PJJ adalah pendidikan yang peserta didiknya terpisah dari pendidik dan pembelajarannya menggunkan teknologi komunikasi, informasi dan media lain. PJJ terbagi dua dalam pelaksanaannya, yaitu pembelajaran yang dilaksanakan dalam jaringan (daring) dan pembelajaran yang dilaksanakan di luar jaringan (luring).

SMP Negeri 12 Solok Selatan menerapkan sistem pembelajaran daring kombinasi luring pada semester ganjil tahun ajaran 2020/2021 dan pada semester genap sekolah sudah bisa melaksanakan pembelajaran secara tatap muka namun dengan waktu yang lebih singkat dibandingkan sebelumnya dengan tetap mematuhir protokol kesehatan. Sekolah menerapkan sistem pembelajaran kombinasi antara daring dan luring. Hal ini menyesuaikan dengan keadaan sarana dan prasarana serta kesiapan guru maupun siswa untuk melaksanakan proses belajar dan mengajar. Begitu juga dalam pelaksanaan pembelajaran Pendidikan Agama Islam dan Budi Pekerti (PABP) pada kelas 8 dilaksanakan secara daring kombinasi luring. Setelah memenuhi syarat, sekolah menerapkan pembelajaran secara tatap muka dengan ketentuan-ketentuan yang sudah ditentukan.

Pembelajaran dilaksanakan secara daring kombinasi luring karena tidak memenuhinya sarana dan prasana untuk belajar secara daring seutuhnya. Guru PABP juga belum mampu bisa mengaplikasikan form pembelajaran secara baik sebagai sarana pembelajaran. Selain itu, siswa kesulitan dalam memahami materi yang ia baca sendiri dirumah tanpa penjelasan dari guru disekolah. Guru juga kesulitan dalam menghadapi sikap siswa yang semakin menurun dengan sistem pembelajaran dari rumah. Kemudian pada saat pembelajaran dilaksanakan secara tatap muka, terdapat problematika yang dirasakan guru dan siswa diantaranya adalah proses pembelajaran tidak dapat berjalan normal, sehingga tidak bisa melaksanakan praktek dari pembelajaran, seperti praktek shalat sunnah, menyetor hafalan, bahkan guru hanya sempat menyampaikan indikator pembelajaran didalam kelas. Akibatnya siswa mengalami kesulitan dalam memahami materi PABP, merasa tugas yang diberikan terlalu banyak sehingga membebani siswa belajar dirumah.

Tujuan dari penelitian ini adalah untuk mendeskripsikan problematika pembelajaran PABP yang dirasakan oleh guru PABP kelas 8 SMP Negeri 12 Solok Selatan serta mendeskripsikan solusi untuk mengatasi problematika yang terjadi. Adapun manfaat yang yang ingin dicapai dari penelitian ini adalah untuk memberikan pengetahuan dan pengalaman bagi guru mengenai pembelajaran Pedidikan Agama Islam dan Budi Pekerti pada masa pandemi covid-19 ataupun pada masa yang mengakibatkan pembelajaran tidak bisa dilaksanakan secara normal. Pada penelitian ini peneliti lebih memfokuskan penelitian pada problematika yang dirasakan pleh guru PABP di SMP Negeri 12 Solok Selatan. 


\section{Tinjauan Pustaka}

\section{A. Pendidikan Agama Islam dan Budi Pekerti}

\section{Pengertian Pendidikan Agama Islam dan Budi Pekerti}

Pendidikan Agama Islam adalah upaya sadar dan terencana dalam menyiapkan peserta didik untuk mengenal, memahami, mengahayati hingga mengimani, bertaqwa dan berakhlak mulia dalam mengamalkan ajaran agama Islam dari sumber utamanya Kitab Al-Qur'an dan Hadist melalui kegiatan bimbingan, pengajaran, latihan, serta penggunaan pengalaman (Nugraha, 2019).

Pendidikan Agama Islam dalam kurikulum 2013 mendapatkan penambahan kata yaitu Budi Pekerti sehingga menjadi Pendidikan Agama Islam dan Budi Pekerti disingkat dengan PABP. PABP dapat diartikan sebagai pendidikan yang memberikan pengatahuan dan membentuk sikap, kepribadian dan keterampilan peserta didik dalam mengamalkan pelajaran agama Islam, yang sekurang-kurangnya dilaksanakan dalam semua jenjang pendidikan. Berdasarkan Permendikbud Nomor 35 tahun 2018 waktu pembelajaran untuk mata pelajaran PABP (Pendidikan Agama Islam dan Budi Pekerti) pada kondisi normal adalah 40 menit dikali 3 kali dalam satu minggu.

\section{Tujuan Pendidikan Agama Islam dan Budi Pekerti}

Dalam Permendikbud No. 67 tahun 2013 Pendidikan Agama Islam dan Budi Pekerti bertujuan untuk: (1) Menumbuhkembangkan akidah melalui pemberian, pemupukan dan pengembangan pengetahuan, pengamalan, pengamalan, pembiasaan serta pengalaman peserta didik tentang Agama Islam sehingga menjadi muslim yang terus berkembang keimanan dan ketakwaannya kepada Allah SWT. (2) Mewujudkan peserta didik yang taat beragama, berakhlak mulia, berpengetahuan, rajin beribadah, cerdas, produktif, jujur, adil, etis, disiplin, santunm toleran dan memgembangkan komunitas Islami pada komunitas yang ada di sekolah. (3) Membentuk peserta didik yang berkarakter melalui pengenalan, pemahaman, pembiasaan normanorma dan aturan-aturan yang Islami dalam hubungannya dengang Tuhan, diri sendiri, sesama dan lingkungan secara harmonis, (4) Mengembangkan nalar dan sikap moral yang selaras dengan nilai-nilai Islami dalam kehidupan sebagai masyarakat, warga negara dan warga dunia.

\section{Ruang Lingkup Pendidikan Agama Islam dan Budi Pekerti}

Mata pelajaran PABP dalam Permendikbud No. 68 Tahun 2013 tersusun dalam beberapa materi, yaitu: (1) Al-qur'an dan Hadist. Menekankan pada kemampuan siswa dalam membaca, menulis dan menterjemahkan serta menampilkan dan mengamalkan isi kandungan Al-qur'an dan Hadist dengan baik dan benar, (2) Akidah. Menekankan pada kemampuan siswa dalam 
memahami dan mempertahankan keyakinan, menghayati, meneladani serta mengamalkan sifat-sifat Allah dan nilai-nilai keimanan dalam kehidupan sehari-hari, (3) Fiqh. Menekannkan pada kemampuan siswa dalam memahami, meneladani dan mengamalkan ibadah dan muamalah secara baik dan benar, (4) Sejarah Peradaban Islam. Menekankan kemampuan siswa dalam mengambil pelajaran daei peristiwa-peristiwa bersejarah dalam Islam, meneladani tokoh Islam, dan mampu mengaitkannya dengan fenomenafenomena sosial agar dapat melestarikan dan mengembangkan kebudayaan dan peradaban Islam.

\section{B. Pembelajaran Pada Masa Pandemi Covid-19}

\section{Jenis Pembelajaran Pada Masa Pandemi Covid-19}

\section{a. Pembelajaran Daring Kombinasi Luring}

Sistem pembelajaran yang diterapkan pada masa pandemi covid-19 ini terdiri atas dua diantaranya: Pembelajaran secara daring kombinasi luring dan juga pembelajaran secara tatap muka. Menurut (Sofyana, 2019) pembelajaran daring kombinasi luring adalah pembelajaran yang menggabungkan antara pembelajaran secara daring dan juga luring. Pembelajaran jarak jauh secara daring kombinasi luring disesuaikan dengan kondisi dan sarana pembelajaran yang tersedia.

Guru merencanakan pembelajaran secara jarak jauh, menyediakan waktu, membuat lembar kerja untuk siswa, dan menggunakan buku yang disediakan dari sekolah, bahan ajar dari lingkungan sekitar untuk membantu siswa belajar dari rumah (Gusty, 2020). Guru sebagai pegajar harus mempersiapkan bahan ajar dan segala yang dibutuhkan dalam proses belajar dengan sisitem daring kombinasi luring. Bahan ajar perlu direncenakan sedemikian rupa agar siswa tidak bosan saat belajar.

Adapun menurut (Tambunan,2020) bahan ajar yang digunakan bisa seperti berikut ini: (1) Bahan ajar yang bersifat visual seperti, modul pembelajaran, hand out, buku pelajaran, atau bisa berupa gambargambar/sticker, bagan diagram dan lain-lain, (2) Bahan ajar yang bersifat audio yaitu rekaman pembelajaran yang bisa didengarkan siswa dalam bentuk suara, (3) Bahan ajar yang bersifat video yaitu bahan ajar yang memuat gambar dan suara sebagai sumber pembelajaran.

\section{b. Pembelajaran Tatap Muka}

Tatap muka (face to face) dalam (KBBI, 2021) berarti pertemuan. Menurut (M. Zainul Shidiq, 2018) pembelajaran tatap muka yaitu pembelajaran yang terjadi interaksi langsung antara pendidik dengan peserta didik, tutorial, mandiri dan kombinasi ketiganya. Kegiatan tatap muka adalah kegiatan pembelajaran yang didalamnya terdapat proses interaksi secara langsung 
Yesi Gusmita dan Rahmi Wiza: Problematika Guru Agma Islam dan Budi Pekerti Pada...

antara pendidik dan peserta didik yang terjadi di dalam ruangan belajar atau kelas.

Menurut (Ikhwani, 2020) dalam bukunya ia mengatakan bahwa terdapat karakteristik dasar dalam kegiatan face to face atau tatap muka diantaranya adalah: (1) Terencana dengan baik, (2) Places-based atau pada tempat yang sudah ditentukan, (3) Terdapat interaksi sosial.

Siswa lebih menyukai pembelajaran tatap muka dikarenakan berbagai alasan, mulai dari bisa bertatap muka langsung dengan guru yang mengajar, lebih mudah memahami materi pelajaran karena mendapatkan penjelasan langsung dari guru yang bersangkutan, dan juga menggunakan berbagai media pembelajaran agar siswa mudah memahami materi. Pembelajaran tatap muka biasanya akan memberi kesan berbeda dengan pembelajaran yang dilaksanakan secara daring, karena dalam tatap muka langsung dikelas baik siswa maupun guru akan lebih mudah dalam berkomunikasi dan siswa akan lebih mudah memahami hal yang guru sampaikan mulai dari gerak-gerik dan ekspresi guru saat menerangkan pembelajaran.

\section{Problematika Pembelajaran Pada Masa Pandemi Covid-19}

\section{a. Problematika Pembelajaran Daring Kombinasi Luring}

Menurut (Prayitno, 2015) ada beberapa kekurangan dalam pembelajaran daring kombinasi luring, diantaranya: 1) Beragamnya media pembelajaran yang dibutuhkan, apabila sarana dan prasarana tidak mendukung maka pembelajaran akan sulit dilaksanakan, 2) Tidak meratanya fasilitas yang dimiliki oleh siswa. Seperti smarthphone dan laptop yang bisa mengakses jaringan internet serta kualitas jaringan yang tidak mendukung untuk melaksanakan pembelajaran secara daring, 3) Penggunaan teknologi masih belum dipahami dengan baik oleh masyarakat umum.

\section{b. Problematika Pembelajaran Tatap Muka}

Dalam proses pembelajaran, menurut Rezky dalam (Basar, 2021) terdapat problematika yang dihadapi oleh guru dalam beberapa indikator diantaranya: 1) Proses menyampaikan isi pembelajaran, 2) Proses interaksi antara pendidik dan peserta didik dalam proses pembelajaran, 3) Kualitas pengembangan dan unsur pembelajaran, 4) Mengembangkan bahan ajar agar lebih mudah disampaikan dalam proses pembelajaran, dan 5) Perancangan perangkat Kurikulum dan menyesuaikan dengan kondisi saat ini.

\section{Metodologi}

Penelitian ini menggunakan pendekatan kualitatif dengan metode studi kasus (case studies). Menurut (Mamik, 2015) studi kasus merupakan salah satu jenis penelitian dimana peneliti melakukan eksplorasi secara mendalam terhadap program, kejadian, proses, aktivitas terhadap individu atau kelompok. Pengambilan sampel dilakukan dengan teknik purposive sampling. Pengumpulan data penelitian 
dilakukan dengan menggunakan teknik wawancara, observasi dan dokumentasi. Data penelitian yang sudah didapatkan kemudian dianalisis dengan menggunakan teknik data reduction, display data dan verification/conclusion. Dan untuk menguji keabsahan data peneliti menggunakan teknik triangulasi dan member check.

\section{Hasil dan Pembahsan}

Dalam pelaksanaan pembelajaran Pendidikan Agama Islam dan Budi Pekerti di kelas 8 SMP Negeri12 Solok Selatan pada masa pandemi covid-19, ditemukan beberapa problematika yang menghambat tercapainya tujuan pembelajaran PABP. Problematika tersebut sangat dirasakan oleh guru PABP yang mengajar di kelas 8 selama mengajar pada masa pandemi covid-19. Berdasarkan hasil penelitian yang didapatkan peneliti melalui observasi dan wawancara dengan Bapak Nashendri dan Bapak Fauzi Ahmad selaku kepala sekolah dan wakil kepala sekolah juga dengan Ibu Elfina selaku guru mata pelajaran PABP dan beberapa siswa kelas 8. Maka pembelajaran yang diterapkan di SMP N 12 Solok Selatan ada dua jenis diantaranya:

Pertama, pembelajaran PABP dengan sistem daring kombinasi luring. Hal ini sesuai dengan wawancara peneliti dengan Ibu Elfina yang mengatakan bahwa:

"Sistemnya daring dan luring. Daring bagi anak yang punya whatsapp dan luring bagi siswa yang tidak punya whatsapp".

Menurut (Sofyana, 2019) daring kombinasi luring adalah pembelajaran yang menggabungkan antara pembelajaran secara daring dan juga luring. Pembelajaran daring kombinasi luring diterapkan karena situasi yang tidak memungkinkan untuk melaksanakan pembelajaran daring seutuhnya dikarenakan beberapa hal. Sistem PABP secara daring kombinasi luring diterapkan selama semester awal tahun ajaran 2020/2021 dengan strategi penugasan, Sebelumnya setiap siswa telah dipinjami buku dari perpustakaan sekolah untuk membantu siswa belajar dari rumah dengan mengerjakan tugas yang diberikan oleh guru PABP.

Tahapan selanjutnya siswa menerima tugas dari guru melalui whatsapp dan messenger (bagi siswa yang memiliki handphone) dan menjemput langsung ke sekolah (bagi yang tidak memiliki handphone) yang disampaikan langsung oleh wali kelas. Setelah itu tugas PABP untuk kelas 8 dikumpulkan setiap hari Rabu dan Kamis, dan setiap minggu tugas yang diberikan guru PABP biasanya memuat $1 \mathrm{kd}$ pembelajaran. Kemudian evaluasi pembelajaran PABP dinilai dari tugas yang dikumpulkan siswa.

Kedua, pembelajaran PABP dengan sistem tatap muka. Hal ini sesuai dengan wawancara peneliti dengan Bapak Nashendri pada tanggal 24 Mei 2021 yang mengatakan bahwa:

"jadi pembelajaran yang terakhir, setelah habis lebaran kita menggunakan tatap muka terbatas yang tadinya 40 menit menjadi 20 menit agar bisa cepat pulang".

Pembelajaran tatap muka adalah pembelajaran yang didalamnya terjadi interaksi secara langsung antara guru dan siswa dalam proses belajar mengajar didalam kelas (M. Zainul Shidiq, 2018). Namun dalam hal ini, sistem pembelajaran 
Yesi Gusmita dan Rahmi Wiza: Problematika Guru Agma Islam dan Budi Pekerti Pada...

tatap muka yang diterapkan pada SMP Negeri 12 Solok Selatan berbeda dengan pembelajaran tatap muka yang diterapkan sebelum masa pandemi covid-19. Pembelajaran PABP yanyg berlangsung harus tetap memperhatikan protokol kesehatan. Baik guru maupun siswa harus selalu menggunakan masker dan menjaga jarak serta mencuci tangan sebelum masuk kedalam kelas. Pembelajaran masih berlangsung seperti biasanya, guru mengajak siswa untuk berdo'a sebelum belajar, namun tidak membaca Al-qur'an dan juga asma'ul husna seperti biasanya karena waktu belajar sekarang sangat singkat. Kemudian, guru juga mengambil absen siswa seperti biasanya sebelum memulai pembelajaran. Guru tetap melaksanakan kegiatan pembuka, inti dan penutup dalam mengajar dikelas, namun dalam waktu yang diperpendek.

Guru biasanya langsng pada poin pembelajaran, karena pada masa pandemi ini, materi yang disampaikan hanya materi-materi esensial saja mengingat waktu mengajar guru hanya sebentar. Guru dan siswa juga tetap saling berinteraksi walaupun dari jauh, menanyakan hal yang siswa tidak paham, sembari menjelaskan pelajaran. Kemudian untuk menambah waktu belajar siswa saat berada dirumah, guru memberikan tugas untuk dikerjakan dirumah dan dikumpulkan pada pertemuan selanjutnya. Evaluasi pembelajaran dilaksanakan seperti biasa, siswa mengikuti UH, UTS dan UAS berdasarkan materi yang sudah disampaikan dikelas.

Berdasarkan pembelajaran PABP yang menerapkan dua sistem pembelajaran yaitu kombinasi dan tatap muka, peneliti menemukan tiga problematika yang dirasakan oleh guru PABP di antaranya:

Pertama, penguasaan teknologi oleh pendidik yang masih rendah. Hal ini sesuai dengan observasi peneliti pada bulan November tahun 2020 dengan kondisi seperti berikut: "guru yang mengetahui mengenai form pembelajaran seperti google classroom itu sudah banyak, tetapi tidak tau bagaimana menggunakannya. Hanya ada 3 orang guru yang paham mengenai google classroom, begitu juga dengan zoom. Guruguru rata-rata hanya bisa menggunakan whatsapp dan facebook. Jadi kalau anak-anak ada yang tidak paham, biasanya bisa tanya lewat whatsapp/messenger. hal ini didapatkan peneliti dari pengamatan situasi dan juga berdasarkan cerita guru-guru saat sedang beristirahat". Hal ini menunjukan bahwa guru belu mampu secara maksimal dalam mengajar siswa di masa pandemi ini seperti pendapat (Uno, 2016) yang mengatakan bahwa guru sebagai pengajar membantu peserta didik yang sedang berkembang untuk mempelajari sesuatu yang belum diketahuinya, membentuk kompetensi, dan memahami materi standar yang belum diketahuinya.

Kedua, menurunnya sikap siswa. Hal ini sesuai dengan hasil wawancara peneliti dengan Ibu Elfina selaku guru PABP pada tanggal 23 Mei 2021 mengatakan bahwa:

"Sikap siswa tu semakin buruk rasonyo, semakin menurun dengan belajar daring itu, tanggung jawabnya ke sekolah, disiplin datang ke sekolah, disiplin dalam belajar, membuat tugas semakin menurun. Kadang pergi kesekolah pakai tarompa, sebab hukuman dikurangi karena ngga ada waktu untuk menghukum, waktu untuk menasehati juga kurang, anak ndak lo manggunoan wakatu untuk baraja, membawa hp kesekolah juga untuk bermain game". 
Berdasarkam ungkapan guru PABP di atas, menunjukan bahwa siswa mengalami degradasi sikap, terlihat dari rendahnya rasa tanggung jawab, kedisiplinan, dan juga sikap sopan santun terhadap guru disekolah. Hal ini menrupakan problematika yang sangat dirasakan oleh guru PABP sebagai akibat siswa terlalu sibuk dengan hal di luar sekolah dan lalai dengan kebiasaan-kebiasaan ketika belajar di sekolah.

Ketiga, intensitas waktu belajar yang singkat. Hal ini sesuai dengan hasil wawancara peneliti dengan Bapak Fauzi Ahmad dan Ibu Elfina pada tanggal 23 Mei 2021 mengatakan bahwa:

"yang menyebabkan kesulitan yaa itu pengaruh dari waktu belajar dikurangi" dan "kesulitannya waktu, waktu PBM diperkecil".

Seperti ungkapan (Suardi, 2018) bahwa belajar ditandai dengan adanya perubahan pada diri seseorang, terlihat dari hasil pola pikir yang baru, muncul pemahaman yang baru, keterampilan baru yang menjadikan kebiasaan baru bagi diri seseorang. Belajar Pendidikan Agama Islam dan Budi Pekerti merupakan ilmu penerapan yang membutuhkan banyak praktek dalam pembelajarannya seperti hasil wawancara dengan Ibu Elfina yang mengatakan:

"apalagi kalau PABP, PAI itu banyak ilmunya itu ilmu penerapan. Kalau hanya sekedar tau tapi tidak diterapkan... ngga bisa praktek pembelajaran, Kd nya diperpendek/disederhanakan, kalau awalnya 13 kd menjadi 11 kd, sebenernya bukan semakin pendek tapi malah disatukan. Contohnya hukum penyembelihan hewan aqiqah dan qurban, itu dulunya kd nya dipisahkan".

Dari berbagai peroblematika yang dihadapi oleh guru dalam mengajarkan mata pelajaran PABP pada kelas 8 di masap pandemi, peneliti menemukan beberapa solusi yang dilakukan guru dan juga sekolah untuk mengatasi masalah yang diantaranya:

Pertama, sekolah mengadakan pembimbingan dan pelatihan. Hal ini sesuai dengan hasil observasi yang dilakukan peneliti pada November 2020 dengang kondisi: "sekolah mengadakan pelatihan dan pembimingan yang diadakan selama satu hari mengenai form pembelajaran seperti google classroom dan zoom meeting. Guru-guru diajarkan bagaimana cara menggunakan dan mengaplikasikan classroom dan zoom meeting". Kesulitan guru dalam menguasai teknologi adalah masalah yang cukup serius pada saat ini. Karena untuk dapat melaksanakan pembelajaran melalui form pembelajaran online, guru harus mampu mengaplikasikannya terlebih dahulu. Oleh karena itu, pihak sekolah mengambil tindakan untuk meningkatkan kompetensi guru SMP Negeri 12 Solok Selatan dengan cara mengadakan pelatihan dan pembimbingan dalam menggunakan form pembelajaran online seperti google classroom dan zoom meeting.

Kedua, guru menerapkan sistem penugasan. Hal ini sesuai dengan hasil wawancara peneliti dengan Bapak Fauzi Ahmad pada tanggal 24 Mei 2021 yang mengatakan bahwa: 
Yesi Gusmita dan Rahmi Wiza: Problematika Guru Agma Islam dan Budi Pekerti Pada...

"kemudian agar anak banyak waktu belajarnya, diusahakanlah guru memberikan tugas untuk belajar dirumah lewat tugas-tugas yang diberikan setiap minggunya".

Waktu untuk pembelajaran PABP di dalam kelas yang sedikit menjadi kesulitan utama bagi guru juga bagi siswa. Karenanya guru tidak bisa maksimal dalam menyampaikan pelajaran kepada siswa di dalam kelas. Berdasarkan hal ini, guru menerapkan sistem penugasan dengan cara memberikan tugas kepada siswa agar siswa lebih banyak membaca materi pelajaran saat dirumah.

Ketiga, meningkatkan motivasi belajar siswa. Hal ini sesuai dengan hasil observasi dengan kondisi: "guru kelas selalu mengingatkan siswa melalui grup whatsapp untuk mengumpulkan tugas tepat waktu, guru juga mengatakan agar mengingatkan teman yang lain juga untuk mengerjakan tugas" dan juga wawancara peneliti dengan Ibu Elfina pada tanggal 24 Mei 2021 yang mengatakan bahwa: "Peranan orang tua sangatlah penting besar, karna anak banyak menghabiskan waktu dirumah dibwah pengawasan orang tua. Sebaiknya orang tua terus mendukung dan mengingatkan anak untuk belajar, mengerjakan tugas, sholat, serta membaca buku paket yang dipinjamkan dari sekolah".

Dalam pelaksanaannya, guru PABP selalu berkoordinasi dengan wali kelas untuk selalu mengingatkan siswa untuk mengumpulkan tugas tepat waktu, memanfaatkan waktu semaksimal mungkin saat berada di dalam kelas untuk menasehati dan mengingatkan siswa untuk tidak malas belajar. Guru PABP juga terus mengingatkan siswa agar mencatat semua tugas-tugas sekolah dalam buku agenda agar tidak lupa untuk mengerjakan, juga mengingatkan untuk mengisi buku agenda sholat dan amalan yaumi.

\section{Simpulan}

Pelaksanaan sistem pembelajaran secara daring kombinasi luring dan juga tatap muka pada mata pelajaran Pendidikan Agama Islam dan Budi Pekerti mengalami berbagai macam tantangan dan kesulitan. Seperti halnya yang dihadapi oleh guru PABP dalam mengajar di kelas 8, guru tidak bisa menerapkan pembelajaran secara daring dikarenakan penguasaan terhadap teknologi yang masih rendah selain tidak terpenuhinya sarana dan prasaeana. Guru juga menghadapi penurunan sikap siswa yang cukup signifikan setelah beberapa bulan menerapkan pembelajaran secara daring kombinasi luring, dan guru juga mengalami kesulitan ketika sistem pembelajaran secara tatap muka dikarenakan waktu belajar yang lebih singkat dari sebelumnya. Adapun berbagai masalah tersebut dapat diatasi dengan melakukan pelatihan dan pembimbingan terhadap guru untuk meningkatkan kompetensi dalam penguasaan teknologi, menerapkan sistem penugasan agar anak lebih banyak belajar di rumah, dan juga meningkatkan motivasi belajar siswa dengan cara terus mengingatkan siswa dalam belajar dan mengerjakan tugas. Beberapa masalah sudah teratasi oleh solusi yang dilaksanakan, namun maih ada beberapa masalah yang belum bisa teratasi. 


\section{Referensi}

Gusty, S., Nurmiati, \& Muliana. (2020). Belajar Mandiri: Pembelajaran Daring di Tengah Pandemi Covid-19. Yayasan Kita Menulis

M. Zainul Shidiq, M. N. (2018). Pengaruh Pembelajaran Tatap Muka terhadap Kemampuan Afektif Warga Belajar Pendidikan Kesetaraan Paket C di PKBM Suaka Anak Negeri Jember. Jurnal Pendidikan Luar sekolah, 14-16. Retrieved Januari 13, 2021

Mamik. (2015). Metode Kualitatif. (C. Anwar, Ed.) Sidoarjo: Zifatama Publisher. Retrieved April 12, 2021

Kementrian Pendidikan dan Kebudayaan Republik Indonesia. Lampiran Peraturan Menteri Pendidikan dan Kebudayaan Nomor 67 Tahun 2013 tentang Kerangka Dasar dan Struktur Kurikulum Sekolah Dasar/Madrasah Ibtidaiyah.

Kementrian Pendidikan dan Kebudayaan Republik Indonesia. Lampiran Peraturan Menteri Pendidikan dan Kebudayaan Nomor 68 Tahun 2013 tentang Kerangka Dasar dan Struktur Kurikulum Sekolah Menengah Pertama/Madrasah Tsanawiyah.

Rusman. (2017). Belajar dan Pembelajaran Berorientasi pada Standar Proses Pendidikan. Jakarta: Kencana.

Sofyana, L., \& Rozaq, A. (2019). Pembelajaran Daring Kombinasi Berbasis Whatsapp pada Kelas Karyawan Prodi Teknik Informatika Universitas PGRI Madiun. Jurnal Nasional Pendidikan Teknik Informatika (JANAPATI), 8(1), 81. https://doi.org/10.23887/janapati.v8i1.17204

Suardi, M. (2018). Belajar \& Pembelajaran. Yogyakarta: Budi Utama.

Tambunan, H., Silitonga, M., \& Sidabutar, U. B. (2020). Blendeed Learning dengang Ragam gaya Belajar. Yayasan Kita Menulis.

Uno, H. B., \& Lamatenggo, N. (2016). Tugas Guru dalam Pembelajaran: Aspek yang Mempengaruhi. Jakarta: PT Bumi Aksara.

Nugraha, d. d. (2019). Motivasi dan Pembelajaran Pendidikan Agama Islam. Wonosobo: Mangku Bumi media. 